\title{
Respons Curvularia lunata Penyebab Penyakit Bercak Daun Kelapa Sawit terhadap Berbagai Fungisida
}

\author{
Response of Curvularia lunata The Causal Agent of \\ Oil Palm Leaf Spot Disease to Various Fungicides
}

\author{
Agus Susanto*, Agus Eko Prasetyo \\ Pusat Penelitian Kelapa Sawit, Medan 20158
}

\begin{abstract}
ABSTRAK
Penyakit bercak daun kelapa sawit yang disebabkan Curvularia sp. merupakan penyakit utama di pembibitan. Pengendalian penyakit biasanya dilakukan secara preventif dengan menerapkan praktik pembibitan yang baik. Apabila terjadi epidemi penyakit biasanya digunakan fungisida. Penelitian ini bertujuan mengidentifikasi penyebab penyakit bercak daun kelapa sawit dan menduga inang alternatif potensialnya di sekitar pembibitan, menyeleksi berbagai bahan aktif fungisida, dan mempelajari pengaruh pergiliran jenis fungisida terhadap insidensi bercak daun. Hasil penelitian menunjukkan bahwa penyakit bercak daun kelapa sawit disebabkan oleh cendawan Curvularia lunata. Penyakit ini juga ditemukan pada rumput teki (Cyperus rotundus) dan alang-alang (Imperata cylindrica). Fungisida yang mampu menekan perkembangan penyakit bercak daun ialah yang berbahan aktif difekonazol, tembaga oksida, dan propineb. Aplikasi secara bergantian atau rotasi antara fungisida difeconazol dan tembaga oksida dengan frekuensi setiap 10 hari dapat menekan perkembangan penyakit bercak daun kelapa sawit di pembibitan.
\end{abstract}

Kata kunci: alang-alang, difeconazol, pembibitan, rumput teki, tembaga oksida

\begin{abstract}
Leaf spot disease of oil palm caused by Curvularia sp. is the major disease in nursery. Implementation of best nursery practices is the key to prevent it. Generally, fungicides are used only if epidemic of leaf spot diseases occur in the field. The objectives of this research were to determine causal agent of leaf spot disease of oil palm and the potential alternative weed host around the nursery, to select suitable fungicides, and to study the effect of fungicides rotation to disease incidence. The results showed that the causal agent of leaf spot disease of oil palm was Curvularia lunata. The fungus was also found on grasses, Cyperus rotundus and Imperata cylindrica. Difeconazol, copper oxide, and propineb suppressed leaf spot disease in nursery. Application of fungicide by rotation between difeconazol and copper oxide with frequency every 10 days suppressed the development of leaf spot disease of oil palm in the nursery.
\end{abstract}

Key words: copper oxide, Cyperus rotundus, difeconazol, Imperata cylindrica, nursery

\section{PENDAHULUAN}

Cendawan Curvularia yang dalam bentuk teleomorfnya adalah Cochliobolus sp. merupakan patogen bagi berbagai tanaman di daerah tropik dan subtropik. Curvularia yang terdiri atas sembilan spesies mampu menginfeksi berbagai tanaman (Watanabe 2002). Curvularia mempunyai kisaran inang yang sangat luas dan dapat ditemukan

*Alamat penulis korespondensi: Pusat Penelitian Kelapa Sawit, Jalan Brigjen Katamso No. 51, Medan 20158 Tel: 061-7862477, Faks: 061-7862488, Surel: marihat_agus@yahoo.com 
di berbagai belahan dunia. Cendawan ini juga berperan sebagai penyebab penyakit pada manusia, yakni penyakit keratitis (endophthalmitis) pada mata setelah terjadi trauma pada mata (Alex et al. 2013).

Curvularia merupakan salah satu cendawan yang menyerang suku Araceae (Yulianty 2005). Curvularia biasa ditemukan pada bibit kelapa. Curvularia yang menyerang asparagus adalah Curvularia lunata (85\%), C. pallescens (32\%), C. eragrostidis (18\%), dan C. barchyspora (11.5\%) (Salleh et al. 1996). Salah satu patogen terbawa benih kakao hibrida ialah C. geniculata (Baharudin et al. 2012) serta $C$. lunata dapat menyebabkan penyakit bercak daun pada berbagai kultivar bibit pisang dengan intensitas penyakit sampai 1-32\% (Soesanto et al. 2012). Di Timur Tengah, Curvularia juga menyerang buah kurma (Atia 2011).

Pada tanaman kelapa dan kelapa sawit, cendawan ini merupakan penyebab penyakit utama yang menyerang pada stadium pembibitan yang sering disebut dengan penyakit bercak daun. Penyakit bercak daun yang disebabkan oleh Curvularia sp. di pembibitan kelapa sawit dapat mencapai 38\% (Solehudin et al. 2012). Penyakit dapat menyebabkan kematian bibit kelapa sawit apabila penyakit ini tidak dikendalikan. Curvularia juga ditemukan sebagai penyebab penyakit bercak daun kelapa sawit di Venezuela (Escalante et al. 2010), di Thailand Selatan (Kittimorakul et al. 2013), dan di Kamerun (Oben et al. 2011).

Pengendalian penyakit bercak daun sangat berkaitan dengan kesehatan bibit kelapa sawit. Bibit kelapa sawit yang dalam kondisi lemah akibat kurang pemupukan dan penyiraman akan menjadi faktor predisposisi penyakit bercak daun. Kelembapan yang tinggi pada bibit kelapa sawit akibat terlambatnya pindah tanam dari pembibitan prenursery ke main nursery juga akan memperparah penyakit ini (Purba et al. 1999). Praktik pengendalian penyakit bercak daun yang paling sering dilakukan ialah sanitasi daun terinfeksi dan aplikasi fungisida dengan bahan aktif mancozeb dengan interval $7-10$ hari (Utomo
1987). Aplikasi fungisida dengan bahan aktif mancozeb dalam waktu yang sangat lama akan menyebabkan resistensi Curvularia terhadap fungisida ini.

Oleh karena itu, pemilihan bahan aktif fungisida lain dan cara aplikasinya akan sangat membantu pengendalian penyakit bercak daun. Pengendalian secara kimiawi ini diharapkan tetap kompatibel dengan teknik pengendalian yang lain, yaitu menjaga kesehatan bibit kelapa sawit dengan melaksanakan seluruh pembibitan kelapa sawit sesuai standar dan sanitasi daun terinfeksi. Identifikasi cendawan juga dilakukan untuk konfirmasi penyebab penyakit bercak daun pada kelapa sawit.

\section{BAHAN DAN METODE}

Penelitian ini terdiri atas empat tahap, yaitu penentuan penyebab penyakit bercak daun pada bibit kelapa sawit dan tanaman gulma di dalam dan sekeliling pembibitan, inokulasi buatan Curvularia pada bibit kelapa sawit, skrining fungisida yang efektif, dan aplikasi rotasi fungisida di pembibitan kelapa sawit. Penelitian dilaksanakan di Pusat Penelitian Kelapa Sawit (PPKS) Medan dan pembibitan kelapa sawit di Simpang Bangkal, Kota Waringin Timur, Kalimantan Tengah.

\section{Penyebab Penyakit Bercak Daun di Pembibitan}

Untuk mengetahui penyebab penyakit bercak daun dilakukan isolasi dari daun yang bergejala bercak daun. Daun kelapa sawit yang bergejala bercak daun dipotong dengan ukuran $1 \mathrm{~cm} \times 1 \mathrm{~cm}$ tepat pada daerah yang bergejala. Potongan daun ini selanjutnya secara aseptik diletakkan pada media potato dextrose agar (PDA) di cawan Petri. Miselium cendawan yang muncul dimurnikan. Isolasi cendawan bercak daun juga dilakukan dari gulma rumputan yang ada pada pembibitan tersebut dengan cara yang sama, seperti pada bibit kelapa sawit. Biakan murni cendawan yang berumur 10 hari selanjutnya diamati secara mikroskopi terhadap konidium yang muncul. Pengamatan mikroskopi konidium juga dilakukan secara langsung dengan mengorek 
bercak daun. Cendawan diidentifikasi dengan kunci determinasi (Watanabe 2002).

\section{Inokulasi Curvularia pada Bibit Kelapa Sawit}

Percobaan inokulasi dilakukan untuk memperoleh bibit kelapa sawit yang homogen terserang Curvularia. Bibit kelapa sawit yang terserang selanjutnya akan digunakan pada skrining berbagai bahan aktif fungisida terhadap bercak daun. Sumber inokulum penyakit berupa suspensi patogen didapatkan dengan menghancurkan daun-daun kelapa sawit yang sakit (intensitas penyakit sekitar $50 \%$ ) dan mencampurnya dengan akuades. Penggunaan daun-daun kelapa sawit yang sakit ini dimaksudkan untuk menjaga virulensi cendawan penyebab penyakit tersebut. Proses inokulasi dilakukan dengan sistem penyemprotan. Ada empat perlakuan yang dicoba untuk inokulasi buatan, yaitu $\mathrm{A}$ ( $25 \mathrm{~mL}$ suspensi cendawan $+225 \mathrm{~mL}$ akuades atau setara dengan $10^{5}$ konidium $\mathrm{mL}^{-1}$ ), B (75 mL suspensi Curvularia $+175 \mathrm{~mL}$ akuades atau setara dengan $10^{6}$ konidia $\left.\mathrm{mL}^{-1}\right), \mathrm{C}(125 \mathrm{~mL}$ suspensi patogen $+125 \mathrm{~mL}$ akuades atau setara dengan $10^{7}$ konidium $\mathrm{mL}^{-1}$ ), dan kontrol (100\% akuades).

\section{Keefektifan Berbagai Bahan Aktif Fungisida terhadap Bercak Daun Kelapa Sawit}

Jenis bahan aktif fungisida yang dicoba adalah tembaga oksida, campuran karbendazim dan mankozeb, klorotalonil, tebukonazol, propineb, mankozeb, benomil, difekonazol, dan kontrol. Dosis yang digunakan adalah $2 \mathrm{gL}^{-1}$ atau $2 \mathrm{mLL}^{-1}$ sesuai dengan formulasinya. Masing-masing fungisida dicampur dengan pelarut air dan dimasukkan dalam tangki semprot yang berbeda-beda antarfungisida. Alat semprot berkapasitas 5 L digunakan untuk 100 bibit kelapa sawit. Wadah pencampuran yang digunakan juga berbeda-beda untuk menghindari terjadinya pencampuran antarfungisida. Masing-masing blok perlakuan juga diberi jarak sekitar 1 meter sehingga kemungkinan semprotan fungisida satu ke fungisida yang lain dapat diminimalkan.
Penyemprotan dilakukan pagi hari setiap seminggu sekali. Pengamatan dilakukan setiap seminggu sebelum penyemprotan. Peubah yang diamati ialah perkembangan penyakit bercak daun berdasarkan gejala yang muncul sesuai dengan skor (nilai) yang ditentukan (Tabel 1). Hasil pengukuran skor penyakit selanjutnya digunakan untuk menghitung intensitas penyakit bercak daun pada masingmasing perlakuan. Intensitas penyakit bercak daun dihitung menggunakan rumus:

$$
\mathrm{IP}=\frac{\Sigma(\mathrm{n} \times \mathrm{v})}{\mathrm{N} \times \mathrm{V}} \times 100 \%, \text { dengan }
$$

IP, intensitas penyakit bercak daun; $n$, jumlah daun contoh yang mempunyai nilai skor sama; $\mathrm{v}$, skor daun yang diamati; $\mathrm{N}$, jumlah total daun yang diamati; $\mathrm{V}$, nilai skor tertinggi.

\section{Aplikasi Rotasi Bahan Aktif Fungisida di Pembibitan Kelapa Sawit}

Berdasarkan hasil skrining bahan aktif dipilih dua fungisida terbaik untuk digunakan sebagai bahan pengendalian dalam skala luas pembibitan di lapangan. Penelitian didahului dengan pengamatan intensitas penyakit bercak daun.

Percobaan ini dirancang dalam tiga perlakuan. Pertama, rotasi fungisida difeconazol dan tembaga oksida dengan frekuensi 10 hari dengan konsentrasi $0.2-0.4 \%$ ( $\mathrm{mL} \mathrm{L} \mathrm{L}^{-1}$ atau $\mathrm{g} \mathrm{L}^{-1}$ ). Dosis aplikasi fungsida yang digunakan adalah 500 tanaman untuk 1 tangki (15 L) dengan tetap menggunakan tambahan perekat. Kedua, fungisida mancozeb dengan frekuensi 10 hari, dan ketiga ialah kontrol. Perlakuan ke-1 dan 2 dilakukan pada blok-blok pembibitan yang ada, sedangkan perlakuan kontrol tanpa aplikasi fungisida dilakukan terpisah pada 100 pot kantong plastik tanaman yang terserang bercak daun. Pengamatan intensitas penyakit bercak daun dilakukan setiap bulan.

\section{HASIL}

\section{Penyakit Bercak Daun di Pembibitan}

Penyebab penyakit bercak daun kelapa sawit ialah Curvularia lunata berdasarkan morfologi konidium yang diproduksi 
Tabel 1 Skor penyakit berdasarkan persentase bercak pada daun kelapa sawit

\begin{tabular}{cc}
\hline Skor & Persentase bercak $(\%)$ \\
\hline 0 & 0 \\
1 & $1-25$ \\
2 & $26-50$ \\
3 & $51-75$ \\
4 & $76-100$ \\
\hline
\end{tabular}

langsung pada bercak atau yang berasal dari biakan murni. Koloni cendawan $C$. lunata berwarna abu-abu gelap, seperti kapas atau beludru, pertumbuhan miselum dalam 4 hari ialah 6-7.6 cm. Konidium berukuran 14-28 $\times$ 7-13 $\mu \mathrm{m}$ dengan warna cokelat gelap, soliter, berbentuk bengkok di tengah meskipun tidak median, biasanya mempunyai 3 septa.

Penyakit bercak daun yang disebabkan oleh cendawan $C$. lunata juga ditemukan pada gulma (Cyperus rotundus) di pembibitan kelapa sawit dan gulma Imperata cylindrica di sekitar pembibitan. Morfologi koloni isolat dari C. rotundus dan I. cylindrica sama dengan yang ditemukan pada penyakit bercak daun bibit kelapa sawit.

\section{Inokulasi Buatan Curvularia pada Bibit Kelapa Sawit}

Inokulasi buatan Curvularia sp. pada bibit kelapa sawit diperlukan untuk skrining bahan aktif fungisida. Semakin pekat suspensi akan menghasilkan intensitas penyakit yang semakin tinggi (Tabel 2). Perlakuan $125 \mathrm{~mL}$ suspensi Curvularia termasuk dalam kategori serangan sedang dan perlakuan $25 \mathrm{~mL}$ dan $75 \mathrm{~mL}$ suspensi Curvularia tergolong menyebabkan serangan ringan. Perlakuan suspensi $125 \mathrm{~mL}$ Curvularia di dalam akuades $125 \mathrm{~mL}$ merupakan dosis perlakuan terbaik untuk digunakan dalam proses inokulasi buatan penyakit bercak daun di pembibitan.

Masa inkubasi penyakit bercak daun kelapa sawit ialah 15 hari. Tanaman mulai menunjukkan gejala terinfeksi patogen pada perlakuan $125 \mathrm{~mL}$ suspensi Curvularia pada hari ke-15. Gejala penyakit dimulai dengan adanya titik bercak berwarna kecokelatan yang dikelilingi oleh selaput hitam transparan. Selaput hitam tersebut akan berubah menjadi kuning muda, sedangkan bercak cokelat muda yang terdapat di pusat bercak akan berubah menjadi cokelat tua. Pada hari pengamatan ke27 , bercak cokelat akan membesar sampai \pm $0.5 \mathrm{~cm}$ dan tidak berkembang lagi (Gambar 1). Bercak daun yang telah mencapai ukuran ini kemungkinan akan menghasilkan konidium yang kemudian akan menyebar ke daerah lain di sekitarnya sehingga menjadi bercak-bercak daun yang baru.

\section{Keefektifan Bahan Aktif Fungisida terhadap Bercak Daun Kelapa Sawit}

Bahan aktif fungisida yang mampu menekan perkembangan penyakit bercak daun ialah difekonazol, tembaga oksida, dan propineb dengan intensitas penyakit berturutturut $17.5,21.5$, dan $20 \%$ setelah 12 minggu pengamatan. Intensitas penyakit bercak daun yang diperlakukan dengan fungisida berbahan

Tabel 2 Hasil inokulasi buatan penyakit bercak daun di pembibitan menggunakan beberapa dosis aplikasi

\begin{tabular}{lccc}
\hline Perlakuan & $\begin{array}{c}\text { Tanaman } \\
\text { terinfeksi } \\
(\%)\end{array}$ & $\begin{array}{c}\text { Intensitas } \\
\text { penyakit } \\
(\%)\end{array}$ & $\begin{array}{c}\text { Kategori } \\
\text { serangan } \\
\text { penyakit }\end{array}$ \\
\hline Kontrol (100\% akuades) & 0 & 0 & - \\
A (25 mL suspensi patogen+225 mL akuades) & 33.3 & 8.3 & ringan \\
B (75 mL suspensi patogen+175 mL akuades) & 50 & 12.5 & ringan \\
C (125 mL suspensi patogen+125 mL akuades) & 100 & 29.2 & sedang \\
\hline
\end{tabular}


aktif benomil dan karbendazim + mancozeb masih tinggi, yaitu masing-masing sebesar $37.5 \%$ dan $37 \%$ (Gambar 2).

Aplikasi Rotasi Bahan Aktif Fungisida di Pembibitan Kelapa Sawit

Aplikasi fungisida secara rotasi setiap 10 hari dengan bahan aktif difekonazol dan tembaga oksida menekan perkembangan penyakit bercak daun di pembibitan kelapa sawit. Intensitas penyakit bercak daun mulai menurun setelah 2 bulan aplikasi dan tinggal 9.2\%. Perkembangan bercak baru sudah tidak ada lagi. Perlakuan tunggal fungisida dengan bahan aktif mancozeb tidak mampu menahan perkembangan penyakit bercak daun. Pada bulan ketiga pengamatan, intensitas penyakit masih sebesar $26.6 \%$, meskipun lebih rendah dibandingkan dengan kontrol yang tanpa perlakuan yang sebesar 56.2\% (Gambar 3).

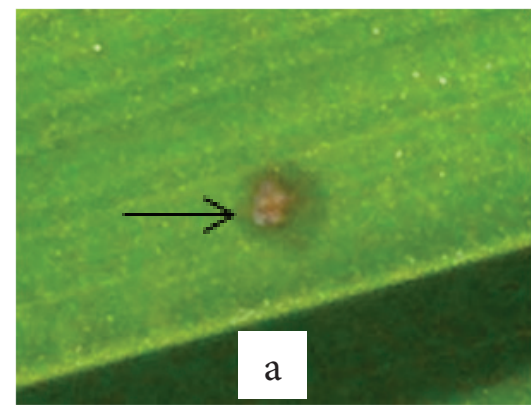

\section{PEMBAHASAN}

Penyebab penyakit bercak daun pada tanaman kelapa sawit ialah Curvularia lunata. Ada tiga genus cendawan yang dikenal sering menimbulkan bercak daun, yaitu Bipolaris, Cochliobolus, dan Curvularia. Ketiganya memiliki karakteristik yang serupa, tetapi berdasarkan analisis kombinasi gen rDNA internal transcribed spacer (ITS), glyceraldehyde 3-phosphate dehydrogenase (GPDH), large subunit (LSU), dan EFI- $\alpha$ (translation elongation factor 1- $\alpha$ ) hanya ada dua grup, yaitu Bipolaris dan Curvularia (Manamgoda et al. 2012).

Curvularia lunata juga ditemukan pada rumput teki dan alang-alang. Oleh karena gulma tersebut diduga merupakan inang alternatif C. lunata maka Curvularia dilaporkan dapat menginfeksi rumput. Bipolaris dan Curvularia

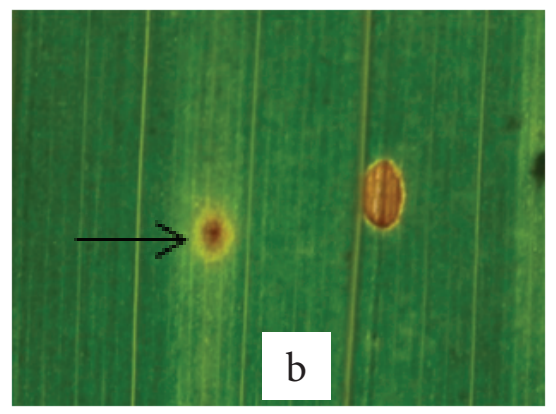

Gambar 1 Gejala penyakit bercak daun di pembibitan kelapa sawit: a, 15 hari setelah inokulasi; dan b, 27 hari setelah inokulasi (kanan).

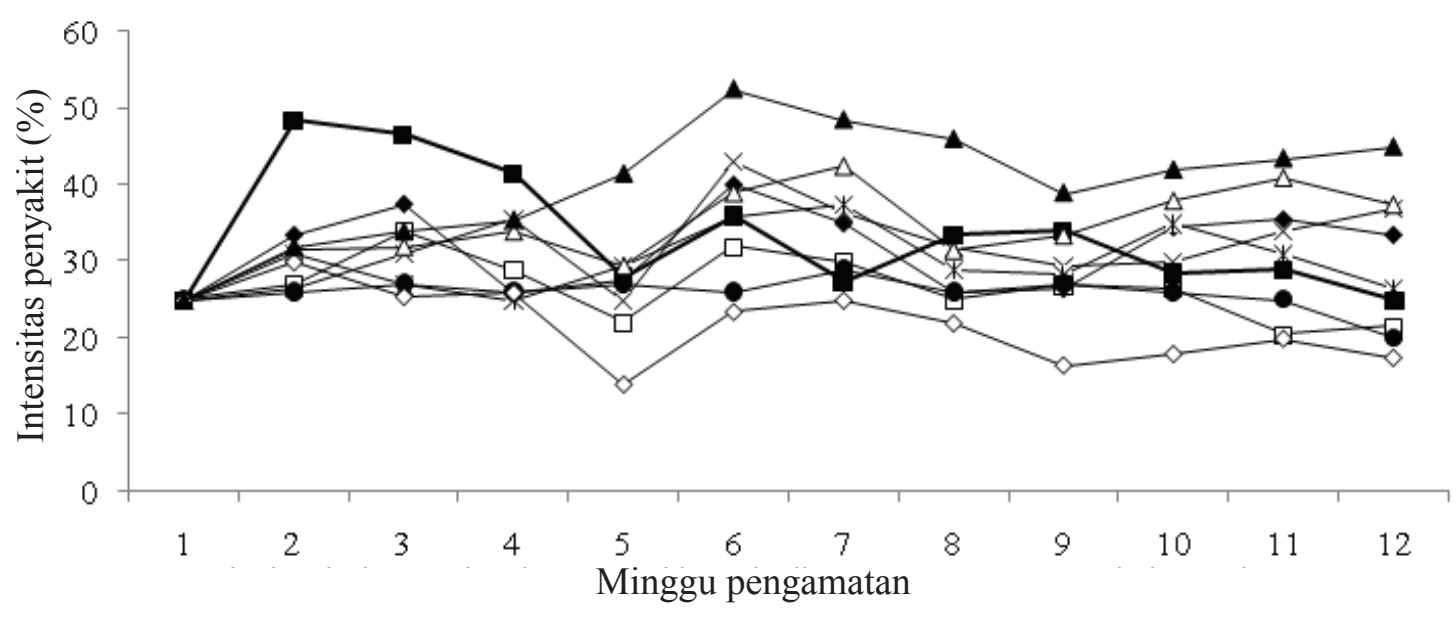

Gambar 2 Intensitas penyakit bercak daun di pembibitan kelapa sawit dengan perlakuan bahan aktif fungisida. $-\times-$, karbendazim + mankozeb; $-\square-$, propineb; $-\bullet-$, benomil; $-\bullet$, , klorotalonil; $\rightarrow$, mankozeb; $\multimap$, difeconazol; $-*-$, tebukonazol; $\rightarrow$, tembaga oksida; $\multimap$, kontrol. 


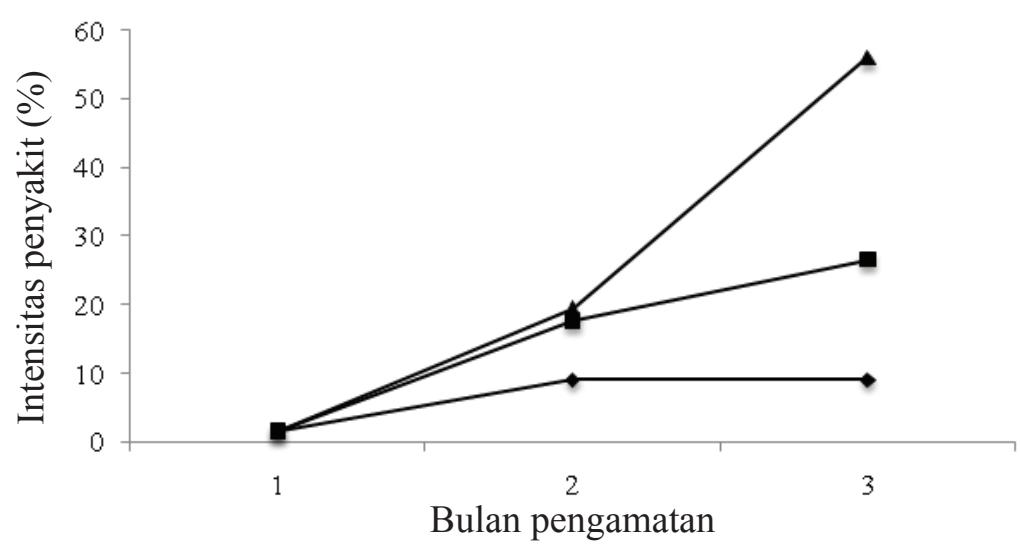

Gambar 3 Perkembangan penyakit bercak daun kelapa sawit pada perlakuan rotasi fungisida. $\rightarrow$, , rotasi difekonazole-tembaga oksida; $\rightarrow-$, mankozeb; $\rightarrow$, kontrol.

merupakan patogen tanaman, khususnya pada rumputan (Poaceae) yang tersebar luas di seluruh dunia (Manamgoda et al. 2012). Curvularia geniculata mampu menyerang Agrostis alba, Andropogon furcatus, Cyperus iria, Oryza sativa, Panicum milaceum, Pennisetum glaucum, P. alopecuroides, Setaria italica, Trifolium repens, Zingber mioga, Zoisia japonica, dan Zymbopogon citratus (Sun et al. 2003).

C. lunata yang menyerang padi dan gandum mempunyai korelasi antara variabilitas genetika dan agresivitas isolat (Ahmad et al. 2006). Meskipun tidak sevirulen Exserohilum rostratum dan Bipolaris spicifera, produksi rumput bermuda Cynodon dactylon di Amerika Serikat sangat diganggu oleh serangan C. lunata (Pratt 2000). Tidak hanya pada tanaman, ternyata Curvularia juga ditemukan di tanah gambut di Sarawak (Omar et al. 2012). Oleh karena itu, aliran air sering juga sebagai agens pembawa cendawan Curvularia.

Impilikasi banyaknya inang alternatif dari Curvularia akan mempengaruhi teknik pengendalian, baik secara langsung maupun tidak langsung. Pengendalian gulma secara tidak langsung akan mengurangi kelembapan di pembibitan. Di berbagai negara iklim mikro sangat mempengaruhi proses infeksi Curvularia, misalnya dapat menimbulkan penyakit bercak daun pada rumput $C$. dactylon jika berada pada suhu di atas $25{ }^{\circ} \mathrm{C}$ (Brecht 2005). Curvularia mampu tumbuh optimal pada suhu $10-40{ }^{\circ} \mathrm{C}$ (Almaguer et al. 2013).
Seringkali, penyebab utama penyakit ini adalah terlambatnya pemindahan bibit dari pre nursery ke main nursery. Tajuk bibit yang telah saling overlapping akan menyebabkan suhu dan kelembapan di sekitar tanaman sangat sesuai bagi proses infeksi patogen.

Pada musim penghujan intensitas penyakit ini tinggi. Tanaman yang lemah akibat kekurangan unsur hara atau akibat transplanting shock dapat mudah terserang penyakit ini (Purba et al. 1999). Pengendalian penyakit yang dianjurkan ialah penggunaan tanaman tahan dan pengendalian secara preventif.

Supaya patogen tidak menjadi resisten, rotasi penyemprotan diperlukan dengan menggunakan lebih dari satu macam bahan aktif fungisida (Purba et al. 1999). Fungisida yang paling awal dan sering digunakan untuk mengendalikan penyakit bercak daun ialah mancozeb. Cara kerja mancozeb adalah mempengaruhi banyak tempat pada cendawan sehingga mengganggu metabolisme lemak, respirasi, dan sistem produksi. Pada awalnya fungisida ini sangat efektif untuk banyak penyakit bercak daun. Mancozeb cocok untuk penyakit bercak lidah buaya India (Aloe barbadensis) (Jat et al. 2013) dan penyakit bercak daun Cercosporidium personatum (Utomo dan Akin 2004). Campuran fungisida mancozeb $73.8 \%$ dan carbendazim $6.2 \%$ efektif menghambat Colletotrichum pada tanaman pakis dengan konsentrasi semprot 0.4\% (Sumardiyono et al. 2011). 
Hasil penelitian sebelumnya menunjukkan bahwa difeconazol dan tembaga oksida mampu menekan penyakit bercak daun kelapa sawit secara tunggal. Difeconazol merupakan fungisida famili triazole yang mempunyai cara kerja menghambat biosintesis ergosterol. Fungisida ini menghambat demetilasi dari sterol C-14 yang pada akhirnya akan memberikan efek pada enzim sitokrom P-450. Difeconazol dilaporkan banyak menghambat perkembangan patogen darikelas Ascomycetes, Basidiomycetes, dan cendawan mitospora. Di lapangan, fungisida ini secara kuratif dapat mengendalikan Alternaria, Ascochyta, Cercospora, Cercosporium, Colletotrichum, Guignardia, Phoma, Ramularia, Septoria, dan Venturia. Difeconazole sangat efektif menekan patogen Venturia inaequalis, Cercospora arachdicola, dan Alternaria solani. Perlakuan 7 hari sebelum dan 1 hari sesudah inokulasi dapat menekan Alternaria solani sebesar 83100\% (Dahmen dan Staub 1992).

Fungisida tembaga oksida mempunyai cara kerja kontak dengan mengganggu transpor energi dan sistem reproduksi cendawan. Apalagi dengan sistem rotasi aplikasi fungisida akan meningkatkan daya bunuh terhadap cendawan dan akan mengurangi terjadinya resistensi terhadap fungisida. Aplikasi rotasi fungisida difeconazol dan tembaga oksida dengan frekuensi setiap 10 hari dapat menekan perkembangan penyakit bercak daun, sedangkan aplikasi fungisida mancozeb secara tunggal tidak sanggup menekan penyakit bercak daun kelapa sawit.

Pengendalian terbaik penyakit bercak daun kelapa sawit adalah dengan menerapkan kultur teknis pembibitan yang baik dan apabila terjadi epidemi penyakit sebaiknya dilakukan pengendalian dengan sanitasi sumber inokulum dan aplikasi fungisida secara rotasi, yaitu difeconazol dan tembaga oksida dengan frekuensi setiap 10 hari.

\section{DAFTAR PUSTAKA}

Ahmad I, Iram S, Cullum J. 2006. Genetic variability and aggresiveness Curvularia lunata associated rice-wheat cropping areas of Pakistan. Pakistan J Bot. 28(2):475-485.

Alex D, Li D, Calderone R, Peters SM. 2013. Identification of Curvularia lunata by polymerase chain reaction in case of fungal endophthalmitis. Med Mycol Case Report. 2:137-140. DOI: http://dx.doi. org/10.1016/j.mmcr.2013.07.001.

Almaguer M, Rojas TI, Dobal V, Batista A, Aira MJ. 2013. Effect of temperature and growth of conidia in Curvularia and Bipolaris species isolated from the air. Aerobiologia. 29(1):13-20. DOI: http:// dx.doi.org/10.1007/s10453-012-9257-z.

Atia MMM. 2011. Efficiency of physical treatments and essential oils in controlling fungi associated with some stored date palm fruits. Aust J Basic Appl Sci. 5(6):1572-1580.

Baharudin, Purwantara A, Ilyas S, Suhartanto MR. 2012. Isolasi dan identifikasi cendawan terbawa benih kakao hibrida. J Littri. 18(1):40-46.

Brecht MO. 2005. Ecology and pathogenicity of Bipolaris spp. and Curvularia spp. associated with decline of ultradwarf bermudagrass golf putting greens in Florida, USA [disertasi]. Florida (US): University of Florida.

Dahmen H, Staub T. 1992. Protective, curative, and eradicant activity of difeconazole against Venturia inaequalis, Cercospora arachdicola, and Alternaria solani. Plant Dis. 76(8):774-777. DOI: http://dx.doi. org/10.1094/PD-76-0774.

Escalante M, Damas D, Márquez D, Gelvez W, Chacón H, Díaz A, Moreno B. 2010. Diagnosis and evaluation of pestalotiopsis, and insect vectors, in an oil palm plantation at the South of Maracaibo Lake, Venezuela. Bioagro. 22(3):211-216.

Jat RN, Jat RG, Nitharwal M. 2013. Management of leaf spot of Indian aloe (Aloe barbadensis Mill.) caused by Curvularia lunata (Wakker) Boedijn. J Plant Sci Res. 29(1):89-93.

Kittimorakul J, Pornsuriya C, Sunpapao A, Petcharat V. 2013. Survey and incidence of leaf blight and leaf spot diseases of 
oil palm seedlings in Southern Thailand. Plant Pathol J. 12(3):149-153. DOI: http:// dx.doi.org/10.3923/ppj.2013.149.153.

Manamgoda DS, Cai L, Mckenzie EHC, Crous PW, Madrid H, Chukeatirote E, Shivas RG, Tan YP, Hyde KD. 2012. A phylogenetic and taxonomic re-evalution of the Bipolaris-Cochiobolus-Curvularia complex. Fungal Divers. 56(1):131-144. DOI: http://dx.doi.org/10.1007/s13225012-0189-2

Oben TT, Etta CA, Oguntade O, Wanobi OO, Mekanya CO. 2011. Bacterial and fungal pathogens associated with diseased oil palm (Elaeis guineensis) plants in Pamol Plantations, Cameroon, Central Africa. Phytopathology. 101:S131.

Omar FN, Ismael NH, Ali SRA. 2012. Fungi associated with deep peat soil Sarawak. Di dalam: UMT 11 th. International Annual Symposium on Sustainability Science and Management; 2012 Jul 9-11; Kuala Trengganu (MY): Universiti Malaysia Terengganu.

PrattRG. 2000. Disease caused by dematiacious fungal pathogens as potential limiting factors for production of bermudagrass on swine effluent applications site. Agr J. 92:512-517. DOI: http://dx.doi. org/10.2134/agronj2000.923512x.

Purba RY, Puspa W, Hutauruk C. 1999. Pedoman teknis hama dan penyakit di pembibitan kelapa sawit. Pusat Penelitian Kelapa Sawit. No 1-1.3, Pub Jan.

Salleh B, Safinat A, Julia L, Teo CH. 1996. Brown spot caused by Curvularia spp., a new disease of asparagus. Biotropia. 9:2637.
Soesanto L, Mugiastuti E, Ahmad F, Witjaksono. 2012. Diagnosis lima penyakit utama karena jamur pada 100 kultivar bibit pisang. J HPT Tropika. 12(1):36-45.

Solehudin D, Suswanto I, Supriyanto. 2012. Status penyakit bercak coklat pada pembibitan kelapa sawit di kabupaten Sanggau. J Perkebunan Lahan Tropika. 2(1):1-6.

Sumardiyono, C, Joko T, Kristiawati Y, Chinta DY. 2011. Diagnosis dan pengendalian penyakit antraknosa pada pakis dengan fungisida. J HPT Tropika. 11(2):194-200.

Sun G, Oide S, Tanaka E, Shimizu K, Tanaka C, Tsuda M. 2003. Species separation in Curvularia "geniculata" group inferred from Brn 1 gene sequences. Mycoscience. 44:239-244. DOI: http://dx.doi.org/10.1007/ S10267-003-0104-5.

Utomo C. 1987. Penyakit daun pada bibitan kelapa sawit di Sumatera Utara. Bul Perkebunan. 18(2):83-88

Utomo, SD, Akin HM. 2004. Ketahanan tiga spesies Arachis terhadap bercak daun akhir (Cercosporidium personatum Berk et Curt) pada pemberian dan tanpa mankozeb. J HPT. 4(2):75-82.

Watanabe T. 2002. Pictorial Atlas of Soil and Seed Fungi. Ed ke-2. Londong (BR): CRC Pr.

Yulianty. 2005. Keanekaragaman jenis-jenis jamur pada daun suku Araceae yang terdapat di beberapa daerah di Indonesia. J Sains Tek. 11(2):89-92. 